\title{
Analysis of The Use of Interpersonal Communication Emoji on Whatsapp Use Among Students
}

\author{
Mohd Zuwiri bin Mat Saad ${ }^{1}$, Nur Hanina Ulfah Jamaludin ${ }^{2}$ and Mohd Hasren Yusuf ${ }^{3}$ \\ ${ }^{1}$ Universiti Utara Malaysia, Sintok Kedah
}

Keywords: Interpersonal communication, emoji, WhatsApp, students

Abstract: The presence of social media has led to changes in the online community participation. Public participation does not only happen in the real world but also in cyberspace (Ali \& Samsudin, 2012). In fact, social media has had a huge impact on community involvement in current issues. Lack of individual knowledge of the emoji forms used, might cause unintentional meaning or purpose to be communicated. The main aim of this study is to identify the forms of emoji that have been used in Whatsapp applications and to study the effects of emoji use in interpersonal communication of the final year student of Universiti Utara Malaysia (UUM). A total of six informants consisting of UUM's final year students who differ from their hometown have committed themselves as informants. This study uses a semi structured interview approach to collect information. The findings show that the forms of emoji used in WhatsApp applications are very important to every individual such as happy, love, dancing, angry, and sad emoji forms depending on how often they are used. In fact, the effects of using emoji in interpersonal communication are also very important factors to look at the level of their reaction with the use of the emoji by looking through four parts namely clear messages, interpretations, interactions and emotions. The effects of using this emoji depend largely on the recipient's interpretations of the emoji sent and their reaction to it.

\section{INTRODUCTION}

The presence of social media has led to changes in the online community participation. Public participation does not only happen in the real world but also in cyberspace (Ali \& Samsudin, 2012). In fact, social medial has had a huge impact on community involvement in current issues. Regardless of whether politics, economics, entertainment or current issues, all information are easily and quickly obtained from social media.

Other studies see the lack of individual knowledge of emoji forms used, that might cause unintentional meaning or purpose to be communicated. Message that contained with emoji presented to the receiver been knowledge as less threatening (Dresner \& Hearing, 2010).

In a past study conducted by Gradiyanto Giovanni Sakti $\mathrm{T}$ entitled Emoticon Meaning in Communication between Personal Social Media Users such as Line among Students, focused on Line Messenger emoticons as a personal communication medium. Line is a popular personal communication medium among students since of the many interesting features available in it. Besides their needs for fast, practical and reachable communication tools, in addition, its main factor is also due to its attractive sticker features that make Line applications increase its use among students.

Summary, the use of incorrect emoji forms by individuals using them is the reason for the impetus of this study. This can be identified by way of posting regardless of the individual situation sent either in a sad state that depicts the individual's disappointment. So there will be conflicts due to the misunderstanding between the parties in the communication they want to convey (West \& Turner, 2008). This will cause disappointment, stress and so on by individuals who face the problem at that point. Additionally, it will spoil existing communications as well as harmless relationships (Garreth W. Tigwell, 2016).

Further research can be seen through the unsatisfactory effect on the use of emoji. Some said that the use of emoji does not have a satisfying effect, which encouraging researchers to see how the techniques or techniques used in delivering an emoji to the recipient so as to cause a less satisfactory effect. According to Zanzotto (2011), this unsatisfactory problem was born of linguistic 
problems in Bahasa Malaysia and indirectly using emoji was very unpretentious to the effect of its use.

Exposure to lack of knowledge in the use of emoji in interpersonal communication also has a tendency in this problem statement. This can be seen in interpersonal communication where the lack of feedback from the recipient about an emoji is delivered. For example, the words "I am sad" accompanied by a smile emoji will provide feedback and instruct them to summarize the matter as what and consider them to be affected by the transmission (Bliss-Carroll, 2016).

\section{METHODS}

The purpose of this study was to examine the use of emoji on interpersonal communication using WhatsApp among students. The study also aims to look at the forms of emoji that have been used by the students themselves according to their frequency of use. In addition, researchers also wanted to see the effects of using emoji in interpersonal communication using WhatsApp among the students themselves.

In order to fulfil the objectives of this study, the researchers conducted an interview session with six informants. They are randomly selected according to the time factor available. There are four divisions in the questions that have been made which cover 40 questions and each section represents 10 questions that relate to clear messages, interpretations, interactions and emotions. The data obtained has been processed using NVivo version 8 app.

Therefore, this study will focus on analyzing the use of emoji on interpersonal communication using WhatsApp among students. Based on the discussion above, there are two questions that have been listed:

i. What emoji forms have been used in Whatsapp applications used by UUM's final year communication student?

ii. How does emoji use affect the interpersonal communication of the final year communication student?

\section{RESULTS AND DISCUSSION}

\subsection{Emoji Used in the WhatsApp application}

The findings show that the use of emoji on interpersonal communication using WhatsApp can be divided into two parts. The first part can be seen on the emoji forms that students (informants) have used according to how often they apply to emoji. These emoji forms are seen through the emoji's frequencies they have used such as happy emoji, love, anger, dancing and sadness. This proves that the use of emoji forms is an important part of the $\mathrm{Y}$ generation because they are able to understand what can be interpreted through emoji as compared to the middle age group.

The statements and opinions provided by the informants reinforce the evidence of the current modernization of the world today. These emoji found in the identified WhatsApp application have helped them to send information according to certain situations and circumstances for the use of the emoji. The findings of this study were also supported by Saussure in Chandler's study (2014) which states that these forms of emoji are easy to interpret and translate. Hence, this has shown that the forms of emoji that they have been using (informants) are a matter of fact that some even prefer emoji alone to provide feedback to the sender.

The West and Tunner (2016) study has shown that the use of incorrect emoji forms by individuals using it has been the reason for the impetus factor in its study. It can be identified through the impulse of its delivery regardless of the individual situation sent either in a sad state that depicts the individual's disappointment and the way it is delivered is like a happy emoji and so forth. Therefore, researchers highlighted the emoji forms that students often use in their WhatsApp application to see how well the emoji is properly utilized.

\subsection{The impression of Use Emoji in Interpersonal Communication}

This section can be seen through the effects of using emoji in the interpersonal communication of the students. In this case, the use of emoji is formed into four parts, namely their clear message, interpretation, interaction and their own emotions. Positive and negative effects can be seen from their own statements, but not least there is also a negative reaction to the use of these emoji. From the point of view of the message, informants say that there is benefaction when using emoji to someone as long as it can be understood. The findings of this study were further reinforced by John Amodeo \& Kris Wentworth (1995), who view that the recipient received messages and decoded by compiling and interpreting elements according to their experience, beliefs and needs. 
Additionally, interpretation can be seen through a complex matter in communication between individuals and becomes a more difficult thing than talking. Although the word "listening" is used alternately with some other words such as hearing and so on but it is one of the unique processes. Opinions provided by informants reinforce their argument about emoji interpretations sent may even be a matter that will cause conflict when a form of emoji is misinterpreted by the recipient. The findings of this study are reinforced by the statements given by Sobur (2003) which define interpretation or perception as receiving stimuli or data from viewing various sources. Therefore, the interpretation of the effect of the use of these emoji plays a significant role for the user to interpret the same meaning as other people.

It can then be seen from the effects of emoji use on interactions. Interaction is a process of giving feedback to others effectively and construct without causing any mistakes. The findings of this study were further reinforced with support by Ben E. Benjamin (2007) stating that feedback and interaction could be a stressful experience for every individual. This is due to the emergence of conflicts due to abuse of emoji form and so on to others. Informants also argue that the interaction with this emoji is one of the things that need to be taken seriously because if the use of the emoji form is wrong, then there will be undesirable conflicts and the interaction will be lousy between the sender and the recipient.

Last but not least, from emotional point of view. The effect of using this emoji also affects one's emotions as previously mentioned because when an emoji form is not appropriate to the situation or the condition of the recipient, it can cause their emotions to be disrupted. In fact, the informant also gave an opinion that the emoji forms to be sent should be first thought before being sent and should also be considered the recipient's situation because they do not want their emotions to be interrupted by the use of the wrong emoji. This opinion is also supported by Croke \& Wolfe (2001) who argue that useful emoji use and emotional management are essential skills for human development. The ability to maximize positive emotions and minimize the negative emotions over time is an important goal for humans. Therefore, it is not anticipated that the use of emoji as appropriate to the recipient's situation can provide a positive atmosphere between the two parties to communicate well.

In the previous study, the previous researcher, Zanzotto (2011), conducted a survey on unsatisfactory results of the use of emoji. The study was conducted to look at the methods or techniques used in delivering emoji to the recipient so that the effect was less satisfactory while Bliss-Carroll (2016) conducted a study on the lack of knowledge disclosure in the use of emoji in interpersonal communication where the lack of feedback of the receiver and so on. Therefore, in this study, researchers have seen the effect of using emoji in interpersonal communication to clear messages, interpretations, interactions and emotions by final year students of UUM's communications department.

Furthermore, it can be concluded that in the aspect of analysing the use of emoji on interpersonal communication using WhatsApp, all informants agreed that emoji have been used in accordance with the situation and condition of the recipient itself but its use should be taken from the perspective of the recipient's own situation. As for the effects of emoji use, some informants have agreed on the question being asked not less than criticize according to their views. This is not a complicated matter, but it is a view of different people. Therefore, the effect of using this emoji has a special interest as well as informants.

Overall, researchers found that the analysis of the use of emoji in interpersonal communication using WhatsApp is very important to the whole of the individual, especially informants who have given their opinions. Therefore, it is certain that they want the use of this emoji to be one of the elements that needed to be emphasized in the process of communication in WhatsApp applications.

\section{CONCLUSIONS}

Summary, this chapter discusses the whole of the research that has been conducted. In fact, the results of this study have also answered the question of the study and have achieved the desired research goal. This study has shown the relevance of the use of emoji forms and the effects of their use in WhatsApp applications by students. The future study may be looking at from another angle, perhaps in terms of subject of the study, such as of middle-aged people who use this emoji and so on. Hence, this study is expected to help students and other stakeholders in the future. 


\section{REFERENCES}

Anh P.Q.Hoang. (2011). Employee's Perception of the Role of Communication with Customers in Service Encounters. Master of Communication Thesis. University of Gothenburg.

Auquib H.L., Firdoos Ahmad Badroo., Khairaj R.C., \& Aqeel Khalique. (2015). Implementation of Forensic Analysis Procedures for Whatsapp and Viber Android Applications. International Journal of Computer Applications. Vol 128-No.12.

Ben E. Benjamin., \& Amy Yeager. (2007). Giving and Getting Effective Feedback. Massage \& Bodywork.

Cresswell, John W. (2009). Research design: Qualitative, quantitative. And mixed method approaches. (3nd ed). SAGE Publications. Inc: University of NebraskaLincoln

Deepa Sethi., \& Manisha Seth. (2009). Interpersonal Communication: Lifeblood of an Organization. Department of Management.

Dian Patria Alan Huda. (2017). Motivasi penggunaan Emoji pada Whatsapp dan kepuasan dalam penyampaian pesan: Studi Korelasi Motivasi Penggunaan Emoji pada Whatsapp dan Kepuasan dalam Penyampaian Pesan di kalangan Mahasiswa Ilmu Komunikasi Angkatan 2014 di Kota Surakata. Ilmu Komunikasi.

Fauzia Zahira Munirul Hakim. (2016). Fungsi Illokasi Smiling Emoji sebagai strategi kesantunan. Alumni Fakultas Ilmu Budaya.

Fred Morstatter., Kai Shu., Suhana Wang., \& Huan Liu. (2016). Cross-Platform Emoji Interpretation: Analysis a Solution and Applications, In Proceedings of ACM Conference. Doi: 10.1145.

Garreth W. Tigwell., \& David R. Flatla. (2016). "On that's what you meant!”: Reducing Emoji Misunderstanding. MobileHCI $16 \quad$ Adjunct. Doi: 10.1145/2957265.2961844.

Giulia Donato \& Patrizia Paggio. (2016). Investigating Redundancy in Emoji Use: Study on a Twitter Based Corpus.

Gradiyanto Giovanni Sakti Y., Muh. Zein Abdullah \& Marsia Sumule. (2016). Makna Emotikon dalam Komunikasi Antar Pribadi pengguna media sosial Line. Ilmu Komunikasi dan Ilmu Politik.

Hannah Miller., Daniel Kluver., Jacob Thebault-Spieker., Loren Terveen., \& Brent Hecht. (2017). Understanding Emoji Ambiguity in Context: The Role of Text in Emoji-Related Mosscommunication.

Ika Destiana., Ali Salman \& Mohd Helmi Abd. Rahim. (2013). Penerimaan Media Sosial: Kajian dalam kalangan pelajar Universiti di Palembang. Malaysian Journal of Communication. Jilid 29(2), 125-140.

Iskandar Shah Mohamed. (2017). Berita Harian: Cabaran Media Konvensional. Retreived from https://www.bharian.com.my/berita/nasional/2017/09/ 331287/cabaran-media-konvensional

Joseph B. Walther., \& Kyle P. D'Addario. (2001). The Impacts of Emoticons on Message Interpretation in
Computer-Mediated Communication. Social Science Computer Review, Vol. 19 No. 3, 324-347.

Karlina Nadya., \& Dasrun Hidayat. (2016). Makna hubungan antarpribadi melalui media online tinder. Jurnal Ilmu Komunikasi, Vol. III No.1.

Muhammad Najib. (2014). Pemaknaan Sticker Emoticon LINE Messenger sebagai Media Komunikasi Interpersonal Mahasiswa Fisipol Universitas Mulawarman. eJournal Ilmu Komunikasi, 2(3), 421430

Nicole L. Bliss-Carroll. (2016). The nature, function, and value of emojis a contemporary tools of digital Interpersonal Communication. Published by Proquest LLC.

Otemuyiwa Abosede Adebola. (2017). Semiotic in the Whatsapp conversations of undergraduate students of Obafemi Awolowo University, Ile Ife, Osun State, Nigeria. International Journal of English and Literature. Retreived from http://www.academicjournals.org/journal/IJEL/articlefull-text/4FADEB164689\# INTRODUCTION

Patrick Acheampong., Li Zhiwen., Frank Boateng., Adelaide B.B., \& Anthony Akai Acheampong Otoo. (2017). Detereminants of Behavioral Intentions of 'Generation-Y' Adoption and USE OF ComputerMediated Communication Tools in Ghana. British Journal of Interdisclinary Research. Vol.8, Issue 1, 2308-3218

Qadar \& Farah. 92017). Self-Talk: Effects on Emotion in Interpersonal Communication Context. Master of Art. The University of Arizona.

Sabrina Chairunnisa., \& Benedicts A.S. (2017). Analysis of Emoji and Emoticon Usage in Interpersonal Communication of Blackberry Messenger and Whatsapp Application User. International Journal of Social Sciences and Management. Vol.4, Issue-2, 120126. Doi: 10.3126/ijssm.v4i2.17173.

Salleh Said. (2017, September 12). Rakyat Malaysia pengguna aplikasi Whatsapp terbanyak dunia. Digital News. Retreived from http://www.astroawani.com/gaya-hidup/rakyatmalaysia-pengguna-aplikasi-whatsapp-terbanyakdunia-salleh-154981

Timothy Achariam. (2015). The sun daily: Malaysian use the internet an average of 12 hours a day. Retreived from http://www.thesundaily.my/news/1633825

The Statistics Poratl. (2017). Number of monthly active WhatsApp users worldwide from April 2013 to July 2017 (in millions). Retreived from https://www.statista.com/statistics/260819/number-ofmonthly-active-whatsapp-users/

Utusan Borneo Online. (2017). Rakyat Malaysia pengguna aplikasi Whatsapp terbanyak dunia. Retreived from http://www.utusanborneo.com.my/2017/09/13/rakyatmalaysia-pengguna-aplikasi-whatsapp-terbanyakdunia 